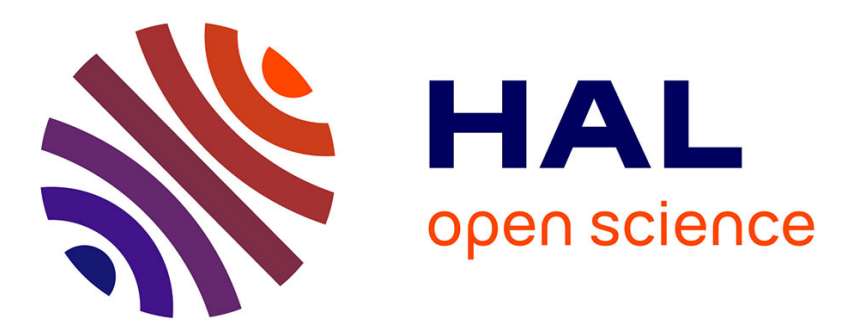

\title{
THE NADPH OXIDASE INHIBITOR VAS2870 IMPAIRS CELL GROWTH AND ENHANCES TGF- $\beta$-INDUCED APOPTOSIS OF LIVER TUMOR CELLS
}

Patricia Sancho, Isabel Fabregat

\section{To cite this version:}

Patricia Sancho, Isabel Fabregat. THE NADPH OXIDASE INHIBITOR VAS2870 IMPAIRS CELL GROWTH AND ENHANCES TGF- $\beta$-INDUCED APOPTOSIS OF LIVER TUMOR CELLS. Biochemical Pharmacology, 2011, 81 (7), pp.917. 10.1016/j.bcp.2011.01.007 . hal-00678042

\section{HAL Id: hal-00678042 https://hal.science/hal-00678042}

Submitted on 12 Mar 2012

HAL is a multi-disciplinary open access archive for the deposit and dissemination of scientific research documents, whether they are published or not. The documents may come from teaching and research institutions in France or abroad, or from public or private research centers.
L'archive ouverte pluridisciplinaire HAL, est destinée au dépôt et à la diffusion de documents scientifiques de niveau recherche, publiés ou non, émanant des établissements d'enseignement et de recherche français ou étrangers, des laboratoires publics ou privés. 


\section{Accepted Manuscript}

Title: THE NADPH OXIDASE INHIBITOR VAS2870

IMPAIRS CELL GROWTH AND ENHANCES

TGF- $\beta$-INDUCED APOPTOSIS OF LIVER TUMOR CELLS

Authors: Patricia Sancho, Isabel Fabregat

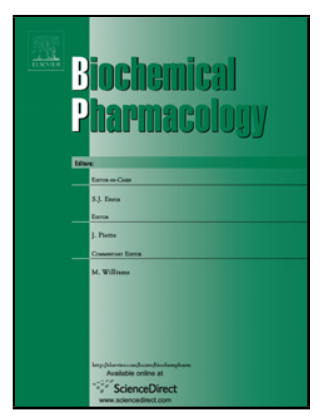

PII:

S0006-2952(11)00064-5

DOI:

doi:10.1016/j.bcp.2011.01.007

Reference:

BCP 10803

To appear in: $\quad B C P$

Received date: $\quad 11-11-2010$

Revised date: $\quad 12-1-2011$

Accepted date: $\quad 13-1-2011$

Please cite this article as: Sancho P, Fabregat I, THE NADPH OXIDASE INHIBITOR VAS2870 IMPAIRS CELL GROWTH AND ENHANCES TGF-?INDUCED APOPTOSIS OF LIVER TUMOR CELLS, Biochemical Pharmacology (2010), doi:10.1016/j.bcp.2011.01.007

This is a PDF file of an unedited manuscript that has been accepted for publication. As a service to our customers we are providing this early version of the manuscript. The manuscript will undergo copyediting, typesetting, and review of the resulting proof before it is published in its final form. Please note that during the production process errors may be discovered which could affect the content, and all legal disclaimers that apply to the journal pertain. 

ENHANCES TGF- $\beta$-INDUCED APOPTOSIS OF LIVER TUMOR CELLS

\author{
Patricia Sancho ${ }^{1}$ and Isabel Fabregat ${ }^{1,2}$
}

From Biological Clues of the Invasive and Metastatic Phenotype Group ${ }^{1}$ and Departament de Ciències Fisiològiques II, Universitat de Barcelona ${ }^{2}$. Bellvitge Biomedical Research Institut (IDIBELL), L'Hospitalet de Llobregat, Barcelona, Spain

E-mails: psancho@idibell.cat,ifabregat@idibell.cat

Address correspondence to: Dr. Patricia Sancho, Biological Clues of the Invasive and Metastatic Phenotype Group, IDIBELL, Gran Via de L'Hospitalet 199, 08907 L'Hospitalet de Llobregat, Barcelona, Spain. Tel: +34932607355. Fax: +34932607426. E-mail:

psancho@idibell.cat

Classification: Pulmonary, Renal and Hepatic Pharmacology 


\section{ABSTRACT}

Liver tumor cells show several molecular alterations which favor pro-survival signaling. Among those, we have proposed the NADPH oxidase NOX1 as a prosurvival signal for liver tumor cells. On the one side, we have described that $\mathrm{FaO}$ rat hepatoma cells show NOX1-dependent partial resistance to apoptosis induced by Transforming Growth Factor beta (TGF- $\beta$ ). On the other side, we have shown that $\mathrm{FaO}$ cells, as well as different human hepatocellular carcinoma (HCC) cell lines, are able to proliferate in the absence of serum through the activation of a NOX1-dependent signaling pathway. The aim of this work was to analyze the effects of NADPH oxidase pharmacological inhibition in liver tumor cells using the inhibitor VAS2870. This compound inhibits dose-dependently autocrine increase of cell number in $\mathrm{FaO}$ rat hepatoma cells, and almost completely blocked ROS production and thymidine incorporation when used at $25 \mu \mathrm{M}$. Such inhibitory effect on autocrine growth is coincident with lower mRNA levels of EGFR (Epidermal Growth Factor Receptor) and its ligand TGF$\alpha$ (Transforming Growth Factor-alpha), and decreased phosphorylation of the EGFR itself and other downstream targets, such as SRC or AKT. Moreover, NADPH oxidase pharmacological inhibition also effectively attenuates serum-dependent growth and phosphorylation of AKT and ERK. Importantly, these inhibitory effects on either autocrine or serum-dependent cell growth are observed in several human HCC cell lines. Finally, we have observed that VAS2870 is also effective in enhancing apoptosis induced by a physiological stimulus, such as TGF- $\beta$. In summary, NADPH oxidase pharmacological inhibition could be considered a promising tool in the treatment of liver cancer.

Keywords: NADPH oxidases, NOX, Reactive Oxygen Species (ROS), proliferation, Hepatocellular carcinoma (HCC) 


\section{INTRODUCTION}

Hepatocellular carcinoma (HCC) is one of the cancers with highest mortality worldwide. Even if the pathogenesis of this disease is highly complex, it is generally well accepted that, in all cases, it exists an unbalance between proliferation and cell death, mainly caused by overactivation of survival pathways [1]. In fact, the main reported signaling pathways implicated in HCC pathogenesis are related to proliferation and angiogenesis [2]. Even though risk factors associated with HCC are well documented, prognosis is usually poor mainly due to the lack of effective therapies. For these reasons, the discovery of new treatments to expand the present therapeutic options is essential in the future handling of the disease.

The NOX family of NADPH oxidases includes 7 different enzymes whose main function is the production of Reactive Oxygen Species (ROS). These enzymes are widely expressed in numerous tissues and play different roles including cell signaling, gene expression regulation, cell death, differentiation and growth [3]. Most of NOX functions are related to signal transduction from membrane receptors and, consequently, they are activated in response to extracellular signals, such as cytokines or growth factors [4].

Hepatocytes express different members of the NOX family. In fact, we have previously described that fetal rat hepatocytes show Nox1, Nox2, and Nox4 expression in basal conditions [5] showing apparent opposite roles in the control of liver cell death. Thus, NOX4 is necessary for the triggering of apoptosis induced by a physiological stimulus, such as the Transforming Growth Factor-beta (TGF- $\beta$ ) [6] or antineoplastic drugs, such as doxorubicin [7]. On the contrary, NOX1 might be involved in protecting cells from TGF- $\beta$ proapoptotic signals in both fetal hepatocytes and hepatoma cells [5,8]. Importantly, we have recently reported an essential role for NOX1 in controlling autocrine growth through the Epidermal Growth Factor Receptor 
(EGFR), a mechanism which seems to be specific for liver tumor cells as compared to non tumoral hepatocytes [9].

According to this, the aim of the present work was to investigate whether NADPH oxidase pharmacological inhibition shows antitumor efficacy in vitro, evaluating both its antiproliferative and proapoptotic activities in rat and human liver cancer cells. Results will show relevance in the design of new therapeutic strategies for liver cancer.

\section{MATHERIALS AND METHODS}

2.1. Cell culture conditions. FaO rat hepatoma cells, Hep3B and HepG2 human hepatocarcinoma cells, SK-HEP-1 human liver adenocarcinoma, and PLC/PRF/5 human liver hepatoma were obtained from the European Collection of Cell Cultures (ECACC). For cell culture, the following media were used: F12 Coon's modified medium (Sigma, Madrid Spain) for $\mathrm{FaO}$, MEM (Sigma, Madrid Spain) for Hep3B and HepG2, 1mM pyruvate-supplemented MEM for SK-HEP-1 and DMEM (Lonza, Basel, Switzerland) for PLC/PRF/5. Cell lines were grown in medium supplemented with $10 \%$ fetal bovine serum and maintained in a humidified atmosphere of $37^{\circ} \mathrm{C}, 5 \% \mathrm{CO}_{2}$. To test autocrine growth, cells were serum deprived at $40 \%$ confluence and, when indicated, the NADPH oxidase inhibitors Apocynin (300 $\mu \mathrm{M}$; Sigma, Madrid, Spain) or VAS2870 (provided by Vasopharm BIOTECH GmbH, Wurzbürg, Germany) were added 30 minutes before serum deprivation and maintained along the experiment. For TGF- $\beta$ experiments, cells at $70 \%$ confluence were serum deprived for 16 hours and treated with $2 \mathrm{ng} / \mathrm{ml}$ TGF- $\beta$ (Calbiochem, La Jolla, CA, USA) in presence or absence of the EGFR inhibitor AG1478 (20 $\mu \mathrm{M}$; Calbiochem) or VAS2870 (25 $\mu \mathrm{M})$, which were added 30 minutes prior to TGF- $\beta$. 
2.2. Analysis of cell number. Cell number was analyzed after crystal violet staining $(0.2 \%$ in $2 \%$ ethanol), as previously described [10].

2.3. Proliferation measurement by $\left[{ }^{3} \mathrm{H}\right]$-thymidine incorporation. Cells were treated during 48 hours as indicated in presence of $1 \mu \mathrm{Ci} / \mathrm{ml}, 1 \mu \mathrm{M}$ thymidine (Hartmann Analytic $\mathrm{GmbH}$, Braunschweig, Germany). Then, cells were incubated for 20 minutes at $4^{\circ} \mathrm{C}$ with $10 \%$ trichloroacetic acid, washed twice with $70 \%$ ethanol and let them dry for at least 1 hour. Finally, the acid precipitated material is resuspended in a buffer containing $2 \% \mathrm{Na} 2 \mathrm{CO} 3,0.1 \mathrm{~N} \mathrm{NaOH}$, $0.5 \%$ SDS and radioactivity was measured in a scintillation counter 1209 Rackbeta (Wallac, Turku, Finland) diluting $100 \mu \mathrm{L}$ of acid precipitated material in $5 \mathrm{ml}$ of scintillation liquid.

2.4. Measurement of intracellular redox state. The oxidation-sensitive fluorescent probe 2',7'dichlorodihydrofluorescein diacetate $\left(\mathrm{H}_{2} \mathrm{DCFDA}\right.$; Invitrogen, Carlsbad, CA, USA) was used to analyze the total intracellular content of ROS as previously described [8]. Fluorescence was measured in a Microplate Fluorescence Reader Fluostar Optima and expressed as percentage of control after correction with protein content.

\subsection{Analysis of caspase-3 activity. Caspase-3 activity was analyzed fluorimetrically upon} incubation of $20 \mu \mathrm{g}$ of cell lysates with $6.6 \mu \mathrm{g} / \mathrm{mL}$ Ac-DEVD-AMC (BD Pharmingen, Franklin Lakes, NJ, USA) for 2 hours at $37^{\circ} \mathrm{C}$ as described previously [8]. Protein concentration of cell lysates was determined using the Bio-Rad protein assay kit (Hercules, CA, USA). Results are calculated as units of caspase-3 activity per microgram of protein per hour and expressed as fold induction relative to control.

2.6. Analysis of gene expression. RNeasy Mini Kit (Qiagen, Valencia, CA, USA) was used for total RNA isolation. Reverse transcription (RT) was carried out using the High Capacity Reverse Transcriptase kit (Applied Biosystems, Foster City, CA, USA), with 500 ng of total RNA from each sample for complementary DNA synthesis. Semiquantitative PCR reactions were performed using specific primers for rat samples:

Nox1: F 5'TTACTACTGCCTCCATCAAGC3'; R 5'GCTGCATACATCACTGTCACG3' 


\title{
Nox2: F 5' TCAAGTGTCCCCAGGTATCC3', R 5' TTCACTGGCTGTACCAAAGG3'
}

Nox4: F 5'TTACTACTGCCTCCATCAAGC3', R 5'GGAATGATTGGATGTCTCTGC3'

Cyclin D1: F 5'ATGTTCGTCCGGTCTAAGATG3', R 5'TGCGGATGATCTGCTTGTTC3'

EGFR: F 5'AAACTCTTCGGGACGCCC AATC3', R 5'TGGCGATGGATGGGATCTTTG3'

HBEGF: F 5'CGGTGGTGC TGAAGCTCTTTC3', R 5'TGGTAACC AGGGAGGCAGTG3'

TGF- $\alpha$ : F 5'TGGTGCAGGAAGAGAAGC3', R 5'TGACAGCAGTGGATCAGC3'

\begin{abstract}
Albumin: F 5'CTGCCGATCTGCC CTCAATAG3', R5'TGCCCACTCTTCCCAGGTTTCT3'
PCR products were obtained after 30-35 cycles of amplification at annealing temperatures of

$57-62^{\circ} \mathrm{C}$, and analyzed by $1.5 \%$ agarose gel electrophoresis. Expression of albumin was

analyzed as a loading control, as indicated. The -RT channel contained RNA that had not been

treated with the RT mixture and is shown as a specificity control.

For Real-Time quantitative PCR, expression levels were determined in duplicate in an

ABIPrism7700 System following manufacturer's protocol. Pre-designed Taqman ${ }^{\circledR}$ primers for NOX1 (Rn00586652_m1), EGFR ( Rn00580398_m1), TGF- $\alpha$ (Rn00446234_m1) and housekeeping GAPDH (Rn99999916_s1) and Taqman® Universal Master Mix were used. All real time reagents were from Applied Biosystems (Foster City, CA, USA).
\end{abstract}

2.7. Western blot analysis. Total protein extracts and Western Blot procedure were carried out as previously described [11]. The antibodies used were: mouse anti- $\beta$-actin (clone AC-15); rabbit anti-phospho-Akt (Ser473), rabbit anti-Akt, rabbit anti-phospho-EGFR (Tyr1068), rabbit anti-EGFR, rabbit anti-phospho-p44/42 MAPK (Thr202/Tyr 204), anti-p44/42 MAP Kinase, rabbit anti-phospho-SRC Family (Tyr416). All antibodies were from Cell Signaling Technology (Beverly, MA, USA), except anti- $\beta$-actin from Sigma (Madrid, Spain). Antibodies were used at 1:1000, except $\beta$-actin (1:3000). Protein concentration was measured with $\mathrm{BCA}^{\mathrm{TM}}$ Protein Assay kit (Pierce, Rockford, USA). 


\section{RESULTS}

\subsection{The NADPH oxidase inhibitor VAS2870 blocks autocrine cell growth of $\mathrm{FaO}$ rat hepatoma cells.}

As we had previously described, $\mathrm{FaO}$ rat hepatoma cells showed autocrine proliferation in absence of serum, doubling the initial cell number in about 48 hours upon serum withdrawal (Fig. 1A). Interestingly, cell growth was accompanied by ROS production, measured by DCFDA oxidation, with a maximal peak of ROS production detected at 6 hours (Fig. 1B). Looking for the source of ROS, we have observed that $\mathrm{FaO}$ rat hepatoma cells only expressed the NADPH oxidase NOX1, differently to adult or fetal rat hepatocytes, which also presented NOX2 and NOX4 expression (Fig. 1C). Consequently, we have found that ROS production is coincident with a NOX1 up-regulation with similar timing (Fig. 1D). Since we have previously demonstrated that NOX1 silencing by a siRNA approach could inhibit autocrine growth [9], we wanted to test the efficiency of the NADPH oxidases pharmacological inhibition in the same experimental conditions. For this purpose, we decided to use the Vasopharm BIOTECH GmbH drug VAS2870, a pharmacological NOX inhibitor, which has been useful to inhibit NADPH oxidases in preclinical assays both in vitro and in vivo $[12,13]$.This compound showed a dosedependent inhibitory effect on cell growth in FaO cells (Fig. 2A), which was maximal at the 25 $\mu \mathrm{M}$ dose. In fact, this concentration was able to completely block ROS production (Fig. 2B) and also cell growth measured both by cell number change kinetically and DNA synthesis by $\left[{ }^{3} \mathrm{H}\right]-$ Thymidine incorporation (Fig. 2C-D). Importantly, the high degree of growth inhibition correlated to much lower expression of cyclin D1, EGFR and TGF- $\alpha$, analyzed at the mRNA level (Fig. 3A). Moreover, apocynin, a widely used NOX inhibitor, produced a similar decrease in the EGFR and TGF- $\alpha$ mRNA levels when compared to VAS2870 (Fig. 3B). Interestingly, phosphorylation of the EGFR itself and some downstream targets such as c-SRC and AKT was almost completely blocked in presence of VAS2870 (Fig. 3C). All these results suggest that 
NADPH oxidase pharmacological inhibition effectively reduce $\mathrm{FaO}$ cells autocrine growth through inhibiting the EGFR pathway at the EGFR and TGF- $\alpha$ expression level.

\subsection{The NADPH oxidase inhibitor VAS2870 blocks serum-dependent cell growth of FaO rat hepatoma cells.}

Since NOX enzymes have been described not only to modulate autocrine cell growth but also proliferation in response to serum and/or mitogenic signals, we decided to test whether VAS2870 was equally effective inhibiting serum-dependent cell growth at the same concentration used for autocrine growth inhibition tests in $\mathrm{FaO}$ cells. As shown in Figure 4, the addition of $25 \mu \mathrm{M}$ VAS2870 inhibited cell number change (Fig. 4A) and DNA synthesis (Fig. $4 \mathrm{~B})$, although growth inhibition in these conditions was less remarkable than that observed upon serum withdrawal. Importantly, basal ROS amount was slightly decreased when VAS2870 was present (Fig. 4C). Those events correlated to decreased AKT and ERK1/2 phosphorylation (Fig. 4D), kinases widely linked to proliferation signaling. However, EGFR phosphorylation was not affected by the inhibitor in presence of serum. In summary, VAS2870 inhibits both autocrine and mitogen-dependent proliferation probably through NOX1 inhibition, although the downstream molecular mechanisms mediating both processes might be different.

\subsection{VAS2870 inhibits proliferation of different human hepatocellular carcinoma (HCC) cell lines}

To better evaluate the possible applicability of NOX pharmacological inhibition for hepatocellular carcinoma treatment, we decided to test VAS2870 effects in different human 


\subsection{VAS2870 pretreatment enhances TGF- $\beta$ - mediated apoptosis of FaO rat hepatoma cells}

By means of siRNA technology, we had previously reported that FaO rat hepatoma cells show partial resistance to TGF- $\beta$-induced apoptosis due to Nox1-dependent ROS [8], process dependent on EGFR activation. For this reason, we wanted to know whether we could achieve a restoration of the apoptotic response to TGF- $\beta$ when cells were pretreated with VAS2870. As shown in Figure 6, FaO cells partially responded to TGF- $\beta$-induced apoptosis, detected by decreased cell number and caspase- 3 activation, response which is enhanced when cells were pretreated with the EGFR inhibitor AG1478 as we have previously described [8]. In a similar manner, NADPH oxidase inhibition with VAS2870 also potentiated TGF- $\beta$-induced apoptosis with comparable efficacy, measuring both the cell number and caspase-3 activity.

In summary, NADPH oxidase pharmacological inhibition effectively decreases proliferation of rat hepatoma and human hepatocellular carcinoma cells, both autocrine and serum-dependent growth, and also enhances the response of hepatoma cells to a physiological proapoptotic stimulus, namely TGF- $\beta$. 


\section{DISCUSSION}

Hepatocellular carcinoma is a major cause of cancer-related deaths worldwide. Risk factors associated with $\mathrm{HCC}$ are well documented, but usually prognosis is negative due to high malignancy of the lesion once diagnosed, and lack of effective therapies [14]. All these facts mean that only $30-40 \%$ of patients are suitable for curative treatments, generally corresponding to liver resection or transplantation [15]. For these reasons, the discovery of new treatments to expand the present therapeutic options is essential in the future handling of the disease.

The main reported signaling pathways implicated in HCC pathogenesis are EGFR/RAS, C-Met, IGF-1, AKT/mTOR, VEGF y PDGFR, all of them related to proliferation and angiogenesis [16]. Interestingly, endogenous ROS production has been described to be very relevant in the cell growth of hepatic tumors $[17,18]$. Moreover, animal models of hepatocarcinogenesis induction mostly have ROS production in common, despite of the cellular targets or cytotoxic effects [19]. In fact, tumor growth inhibition has been described to occur upon antioxidants dietary supplementation in animal models [20]. Moreover, a NADPH oxidase system-derived ROS production has been proposed as main mediator in hepatocarcinogenic processes occurring in different animal models, such as the TGF-alpha/c-myc transgenic mice [20], or exposure to carcinogens such as diethylnitrosamine [21].

NADPH oxidases are enzymes catalyzing the generation of superoxide or hydrogen peroxide using NADPH as electron donor. They were cloned by homology to the phagocytic NADPH oxidase gp91phox (NOX2) and have been described to function as signaling molecules in non-phagocytic cells [22]. In the liver, the isoforms NOX1, NOX2 and NOX4 are expressed by fetal and adult hepatocytes ([5], Fig. 1C), although they might have opposite effects controlling cell death: NOX4 favoring apoptosis whilst NOX1 favors survival $[6,8]$. Interestingly, tumoral hepatocytes show an altered NOX expression pattern, indicating that they have developed mechanisms to repress the pro-apoptotic NOX4 at the transcriptional level and 
expressing NOX1 or other isoforms $[8,23]$. In this sense, we had postulated a pro-tumorigenic role for NOX1 based on the next evidence: 1) NOX1 protects hepatoma cells from physiological proapoptotic signals such as TGF- $\beta$ [8]; and 2) NOX1 might be controlling autocrine growth through the EGFR, a mechanism which seems to be specific for liver tumor cells as compared to non tumoral hepatocytes [9].

For these reasons, we wanted to test in vitro the potential antitumor efficiency of VAS2870, the only validated low-molecular weight pharmacological NOX inhibitor [13, 24]. First of all, we wanted to measure VAS2870 efficiency in inhibiting autocrine growth of $\mathrm{FaO}$ rat hepatoma cells. We corroborated the ROS production concomitant to NOX1 induction during the first hours of autocrine growth (Fig. 1), which was almost totally blocked when VAS2870 was present (Fig. 2). Importantly, EGFR and TGF- $\alpha$ expression levels, and also phosphorylation of EGFR, AKT and SRC were diminished with high efficiency (Fig. 3). Indeed, effects of pharmacological inhibition were equivalent to those obtained by siRNA technology, but more pronounced. High efficacy of this drug might be the result of a full and sustained inhibition of cellular NADPH oxidases, compared to partial and transient ROS inhibition obtained with knock-down experiments.

NOX proteins have been described to transmit signals downstream receptor tyrosine kinases (RTK), such as PDGFR, VEGFR, EGFR, bFGFR and insulin [4], all of them related to the pathogenesis of HCC, as stated above. Those pathways have considerable crosstalks and are redundant in downstream molecules, reason why the only effective chemotherapeutic agent for treatment of patients with non-resectable tumors is the multikinase inhibitor sorafenib [25]. Thus, considering that different RTK might signal through NADPH oxidases, it is reasonable to think that NOX inhibition could affect the downstream signaling through one or several of those receptors at the same time. The results of growth inhibition obtained in presence of serum (Figs. 4 and 5B) also support such hypothesis: 1) on the one hand, serum contains multiple mitogenic molecules and growth factors, so we could consider that more than one pathway is being activated in such conditions; 2) as shown in Figure 4D, VAS2870 inhibits both AKT and ERK 
phosphorylation, previously described as targets of NOX-dependent proliferation in presence of serum [26], without affecting the phosphorylation of the EGFR itself. This fact might also suggest that NADPH oxidases are acting downstream tyrosine kinase receptors. It is worthy to note that VAS2870 inhibitory effect on NOX enzymes is not isoform-specific [13] and the final result might be a combinative effect of inhibiting all the isoforms expressed in the cell. The response to VAS2870 in the human HCC cell lines included in our study, whose NADPH oxidase expression pattern is more complex than the one detected for $\mathrm{FaO}$ cells, indicate the relevance of the proliferative role of NOXes in human liver tumor cells, Indeed, a role for NOX3 in the proliferative response to insulin has been reported in HepG2 cells [27].

Importantly, results obtained with the NADPH oxidase inhibitor VAS2870 in human HCC cell lines (Fig. 5) show the high efficacy of this compound regardless the mutational status of p53 or RAS/RAF pathway. On the one hand, we have chosen for our experiments HepG2 and SK-Hep1 cells presenting over-activation of RAS and B-RAF, respectively $[28,29]$, and we found a high inhibition of the proliferation rate upon incubation with VAS2870 both in presence or absence of serum. On the other hand, Hep3B and PLC/PRF5 cells, p53 defective, also show high inhibition of growth. Importantly, the use of VAS2870 has no toxicity when applied to non tumoral hepatocytes (not shown).

Finally, we have also shown how VAS2870 treatment enhances the apoptotic response induced by TGF- $\beta$ in FaO cells (Fig. 6). In normal conditions, this cytokine is considered to act as a liver tumor suppressor, but many tumor cells acquire resistance to its proapoptotic effects, favoring response to this cytokine in terms of malignancy [30]. In addition to survival signals via NOX1 in hepatoma cells [8], TGF- $\beta$ is able to induce migration of different tumor cells via NOX proteins $[31,32]$ and also promote oxidative damage upon hepatitis $\mathrm{C}$ virus, frequently associated to later HCC $[33,34]$. Thus, inhibiting NADPH oxidases might prevent those events and promote beneficial effects in cases of liver cancer. 
In summary, results presented in this manuscript indicate that NADPH oxidase pharmacological inhibition with VAS2870, effectively impairs both autocrine and mitogendependent growth of liver tumor cells, attenuating downstream intracellular signals that contribute to cell proliferation. Moreover, VAS2870 treatment also enhances apoptosis induced by TGF- $\beta$, a physiological proapoptotic stimulus. Indeed, NADPH oxidase pharmacological inhibition might be a promising therapeutic approach for hepatocellular carcinoma.

\section{ACKNOWLEDGEMENTS}

We would like to thank Beatriz Parejo for her technical assistance. This work was supported by grants from the Ministerio de Ciencia e Innovación, Spain (BFU2006-01036, BFU2009-07219 and ISCIII-RTICC RD06/0020) and AGAUR-Generalitat de Catalunya (2005SGR-00549 and 2009SGR-312). We would like to acknowledge Vasopharm BIOTECH GmbH, Wurzbürg, Germany, which kindly provided us VAS2870.

\section{REFERENCES}

[1] Fabregat, I. Dysregulation of apoptosis in hepatocellular carcinoma cells. World J Gastroenterol 2009; 15:513-20.

[2] Llovet JM, Bruix J. Molecular targeted therapies in hepatocellular carcinoma. Hepatology $2008 ; 48: 1312-27$.

[3] Brown DI, Griendling KK. Nox proteins in signal transduction. Free Radic Biol Med 2009; 47:1239-53.

[4] Petry A, Weitnauer M, Görlach A. Receptor activation of NADPH oxidases. Antioxid Redox Signal 2010;13:467-87. 
[5] Murillo MM, Carmona-Cuenca I, Del Castillo G, Ortiz C, Roncero C, Sánchez A, et al.

Activation of NADPH oxidase by transforming growth factor-beta in hepatocytes mediates upregulation of epidermal growth factor receptor ligands through a nuclear factor-kappaBdependent mechanism. Biochem J 2007; 405:251-59.

[6] Carmona-Cuenca I, Roncero C, Sancho P, Caja L, Fausto N, Fernández M, Fabregat I. Upregulation of the NADPH oxidase NOX4 by TGF- $\beta$ in hepatocytes is required for its proapoptotic activity. J Hepatol 2008; 49: 965-76.

[7] Ortiz C, Caja L, Sancho P, Bertran E, Fabregat I. Inhibition of the EGF receptor blocks autocrine growth and increases the cytotoxic effects of doxorubicin in rat hepatoma cells: role of reactive oxygen species production and glutathione depletion. Biochem Pharmacol 2008; $5: 1935-45$.

[8] Sancho P, Bertran E, Caja L, Carmona-Cuenca I, Murillo MM, Fabregat, I. The inhibition of the epidermal growth factor (EGF) pathway enhances TGF-beta-induced apoptosis in rat hepatoma cells through inducing oxidative stress coincident with a change in the expression pattern of the NADPH oxidases (NOX) isoforms. Biochim Biophys Acta 2009; 1793: 253-63. [9] Sancho P, Fabregat I. NADPH oxidase NOX1 controls autocrine growth of liver tumor cells through up-regulation of the epidermal growth factor receptor pathway. J Biol Chem 2010; 285:24815-24.

[10] Sánchez A, Alvarez AM, Benito M, Fabregat I. Apoptosis induced by transforming growth factor-beta in fetal hepatocyte primary cultures: involvement of reactive oxygen intermediates. J Biol Chem 1996; 271:7416-22.

[11] Caja L, Ortiz C, Bertran E, Murillo MM, Miró-Obradors MJ, Palacios E, Fabregat I. Differential intracellular signalling induced by TGF- $\beta$ in rat adult hepatocytes and hepatoma cells: implications in liver carcinogenesis. Cell Signal 2007; 19: 683-94.

[12] Lange S, Heger J, Euler G, Wartenberg M, Piper HM, Sauer H. Platelet-derived growth factor BB stimulates vasculogenesis of embryonic stem cell-derived endothelial cells by calcium-mediated generation of reactive oxygen species. Cardiovasc Res 2009;81:159-68. 
[13] Kleinschnitz C, Grund H, Wingler K, Armitage ME, Jones E, Mittal M, et al. Post-stroke inhibition of induced NADPH oxidase type 4 prevents oxidative stress and neurodegeneration. PLoS Biol 2010;8 pii: e1000479.

[14] Sherman M. Hepatocellular carcinoma: epidemiology, risk factors, and screening. Semin Liver Dis 2005; 25:143-54.

[15] Rimassa L, Santoro A. The present and the future landscape of treatment of advanced hepatocellular carcinoma. Dig Liver Dis 2010; 42 Suppl 3:S273-80.

[16] Whittaker S, Marais R, Zhu AX. The role of signaling pathways in the development and treatment of hepatocellular carcinoma. Oncogene 2010; 29:4989-5005.

[17] Dong-Yun S, Yu-Ru D, Shan-Lin L, Ya-Dong L, Lian W. Redox stress regulates cell proliferation and apoptosis of human hepatoma through Akt protein phosphorylation. FEBS Lett 2003; 542: 60-4

[18] Laurent A, Nicco C, Chéreau C, Goulvestre C, Alexandre J, Alves A et al. Controlling tumor growth by modulating endogenous production of reactive oxygen species. Cancer Res $2005 ; 65: 948-56$

[19] Tien Kuo M, Savaraj N. Roles of reactive oxygen species in hepatocarcinogenesis and drug resistance gene expression in liver cancers. Mol Carcinog 2006; 45:701-9.

[20] Calvisi DF, Ladu S, Hironaka K, Factor VM, Thorgeirsson SS. Vitamin E down-modulates iNOS and NADPH oxidase in c-Myc/TGF-alpha transgenic mouse model of liver cancer. $\mathbf{J}$ Hepatol 2004; 41:815-22.

[21] Teufelhofer O, Parzefall W, Kainzbauer E, Ferk F, Freiler C, Knasmüller S et al. Superoxide generation from Kupffer cells contributes to hepatocarcinogenesis: studies on NADPH oxidase knockout mice. Carcinogenesis 2005; 26: 319-29.

[22] Fisher AB. Redox signaling across cell membranes. Antioxid Redox Signal 2009; 11:134956.

[23] Caja L, Sancho P, Bertran E, Iglesias-Serret D, Gil J, Fabregat I. Overactivation of the MEK/ERK pathway in liver tumor cells confers resistance to TGF-\{beta\}-induced cell death through impairing up-regulation of the NADPH oxidase NOX4. Cancer Res 2009; 69:7595-602. 
[24] Wind S, Beuerlein K, Armitage ME, Taye A, Kumar AH, Janowitz D et al. Oxidative

stress and endothelial dysfunction in aortas of aged spontaneously hypertensive rats by NOX1/2 is reversed by NADPH oxidase inhibition. Hypertension 2010; 56:490-7.

[25] Llovet JM, Ricci S, Mazzaferro V, Hilgard P, Gane E, Blanc JF, et al. Sorafenib in advanced hepatocellular carcinoma. N Engl J Med 2008; 359:378-90.

[26] Kumar B, Koul S, Khandrika L, Meacham RB, Koul HK. Oxidative stress is inherent in prostate cancer cells and is required for aggressive phenotype. Cancer Res 2008; 68:1777-85.

[27] Carnesecchi S, Carpentier JL, Foti M, Szanto I. Insulin-induced vascular endothelial growth factor expression is mediated by the NADPH oxidase NOX3. Exp Cell Res 2006; $312: 3413-24$

[28] Hsu IC, Tokiwa T, Bennett W, Metcalf RA, Welsh JA, Sun T, et al. p53 gene mutation and integrated hepatitis B viral DNA sequences in human liver cancer cell lines. Carcinogenesis $1993 ; 14: 987-992$.

[29] Davies H, Bignell GR, Cox C, Stephens P, Edkins S, Clegg S, et al. Mutations of the BRAF gene in human cancer. Nature 2002; 417:949-954.

[30] Coulouarn C, Factor VM, Thorgeirsson SS. Transforming growth factor- $\beta$ gene expression signature in mouse hepatocytes predicts clinical outcome in human cancer. Hepatology 2008; 47: 2059-67.

[31] Tobar N, Guerrero J, Smith PC, Martínez J. NOX4-dependent ROS production by stromal mammary cells modulates epithelial MCF-7 cell migration. Br J Cancer 2010; 103:1040-7. [32] Nam HJ, Park YY, Yoon G, Cho H, Lee JH. Co-treatment with hepatocyte growth factor and TGF-beta1 enhances migration of HaCaT cells through NADPH oxidase-dependent ROS generation. Exp Mol Med 2010;42:270-9.

[33] Boudreau HE, Emerson SU, Korzeniowska A, Jendrysik MA, Leto TL. Hepatitis C virus (HCV) proteins induce NADPH oxidase 4 expression in a transforming growth factor betadependent manner: a new contributor to HCV-induced oxidative stress. J Virol 2009; 83:1293446. 
[34] de Mochel NS, Seronello S, Wang SH, Ito C, Zheng JX, Liang TJ, et al. Hepatocyte

$\mathrm{NAD}(\mathrm{P}) \mathrm{H}$ oxidases as an endogenous source of reactive oxygen species during hepatitis $\mathrm{C}$ virus infection. Hepatology 2010; 52:47-59. 


\section{FIGURE LEGENDS}

Figure 1. FaO rat hepatoma cells show autocrine proliferation correlating to ROS production and Nox1 up-regulation. A, B, D. FaO rat hepatoma cells were serum-depleted for the indicated times and it was measured: cell number (A), ROS production (B) and Nox1 expression by real time PCR (D). Data were calculated relative to zero time and represent the mean \pm SEM of three independent experiments. Student's $t$ test calculated versus zero time: $* \mathrm{p}<0.05 ; * * \mathrm{p}<0.01 ; * * * \mathrm{p}<0.001$. In C, RT-PCR comparing NADPH oxidases expression of $\mathrm{FaO}$ cells, adult rat hepatocytes $(\mathrm{AH})$ and fetal hepatocytes $(\mathrm{FH})$.

\section{Figure 2. The NADPH oxidase inhibitor VAS2870 blocks autocrine cell growth and ROS} production. A. FaO cells were serum depleted and treated with the indicated concentrations of the NADPH oxidase inhibitor VAS2870. After 48h, cell number was measured. The concentration of $25 \mu \mathrm{M}$ was selected for the rest of experiments. B. ROS production at 12 hours. C. Cell number at the indicated times. D. DNA synthesis at $48 \mathrm{~h}$. Data were calculated relative to zero time, except in D were it was calculated respect to untreated cells, and represent the mean \pm SEM of three independent experiments. Student's $t$ test calculated versus zero time or untreated cells in D: $* \mathrm{p}<0.05 ; * * \mathrm{p}<0.01 ; * * * \mathrm{p}<0.001$.

\section{Figure 3. Pharmacological inhibition of NOX1 with VAS2870 down-regulates the EGFR} pathway. $\mathrm{FaO}$ cells were treated for 12 hours with the NADPH oxidase inhibitors VAS2870 or Apocynin (300 $\mu \mathrm{M}$, in B) prior to serum depletion. A. RT-PCR. B. EGFR and TGF- $\alpha$ expression measured by Real-time PCR. Data represent the mean \pm SEM of four independent 
experiments. Student's t test calculated as pretreated versus non-pretreated cells: ${ }^{*} \mathrm{p}<0.05 ;{ }^{*} \mathrm{p}<$ 0.01. C. Western blot of total lysates. Albumin (Alb) and $\beta$-actin were used as loading control.

Figure 4. The NADPH oxidase inhibitor VAS2870 decreases serum-induced cell growth and AKT/ ERK phosphorylation. FaO cells were treated with $25 \mu \mathrm{M}$ VAS2870 in presence of serum, and it was determined: A. Cell number at the indicated times. B. DNA synthesis at $48 \mathrm{~h}$. C. ROS production at 12 hours. D. Phosphorylation of EGFR, AKT and ERK1/2 by Western blot at 12 hours. $\beta$-actin was used as loading control. Data were calculated relative to untreated cells, except in A were it was calculated respect zero time, and represent the mean \pm SEM of three independent experiments. Student's $t$ test calculated versus untreated cells or zero time in A: $* \mathrm{p}<0.05 ; * * \mathrm{p}<0.01$

Figure 5. Treatment with VAS2870 inhibits both autocrine and serum-mediated cell growth of different human hepatocellular carcinoma (HCC) cell lines. Hep3B, HepG2, SKHep1 and PLC/PRF5 cells were treated with $25 \mu \mathrm{m}$ VAS2870 in absence (A) or presence (B) of serum, and cell growth was determined after 48 hours by cell number determination (left panels) or DNA synthesis (right panels). Data were calculated relative to zero time for cell number and respect to untreated cells for DNA synthesis, and represented as the mean \pm SEM of three independent experiments. Student's $t$ test calculated versus control cells: ${ }^{*} \mathrm{p}<0.05 ;{ }^{*} \mathrm{p}<$ 0.01 .

Figure 6. VAS2870 enhances TGF- $\beta$-induced apoptosis in $\mathrm{FaO}$ cells, to the same extent as EGFR inhibition with AG1478. FaO cells were serum-depleted for 12 hours, pretreated for 30 minutes with either $25 \mu \mathrm{M}$ VAS2870 or $20 \mu \mathrm{M}$ AG1478, and then incubated in presence or absence of $2 \mathrm{ng} / \mathrm{ml}$ of TGF- $\beta$. A. Caspase activity at 16 hours. B. Cell number at 24 hours. Data 
1 
A

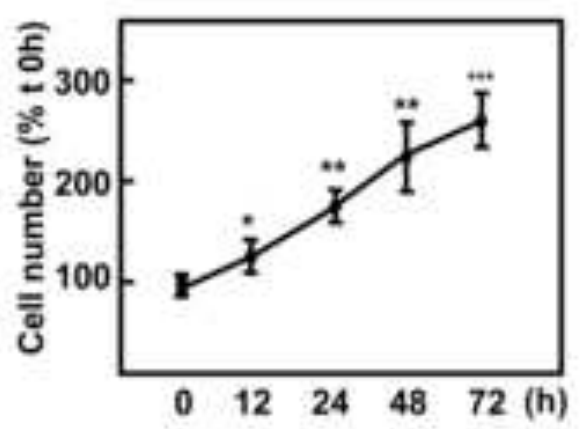

C
B

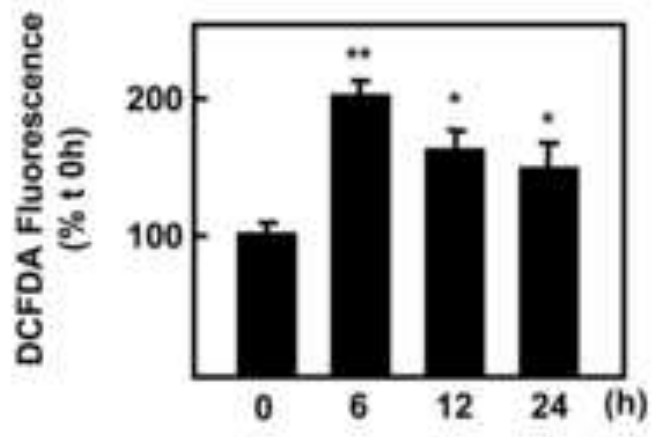

D

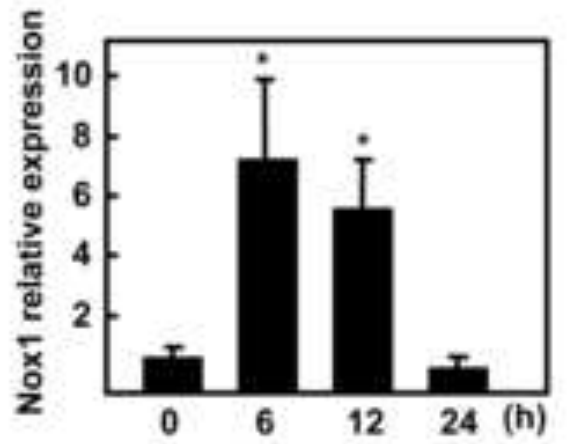

Figure 1 
Figure 2

Click here to download high resolution image

A

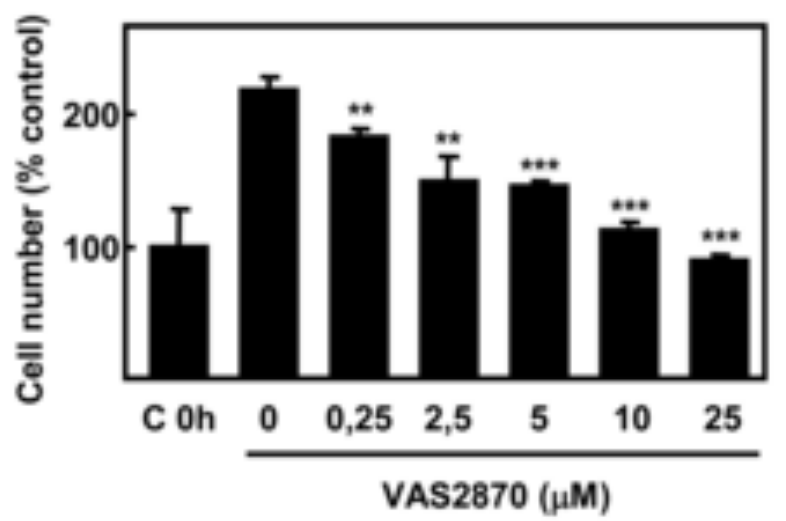

C

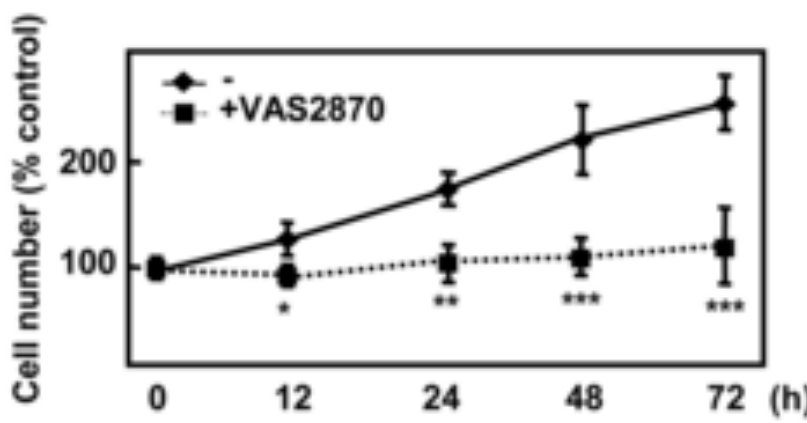

B

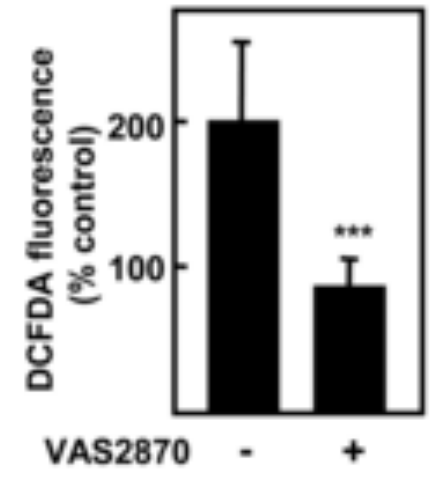

D

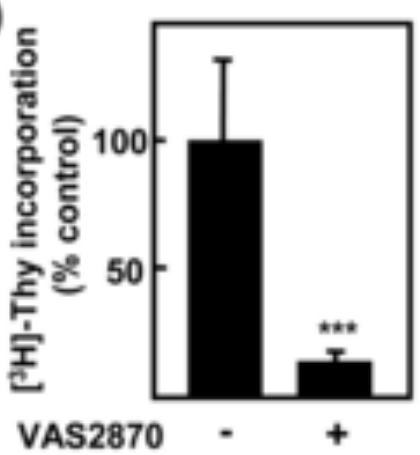

Figure 2 
Figure 3

Click here to download high resolution image

A

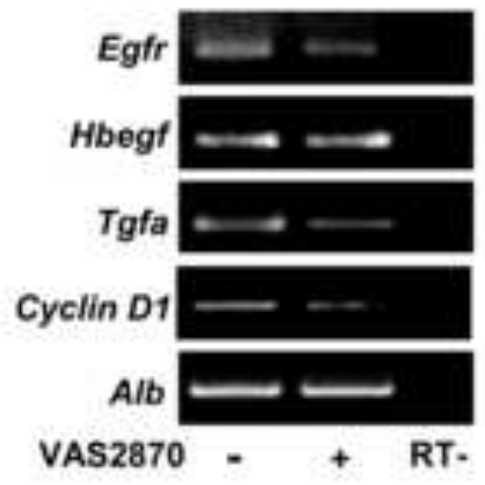

B

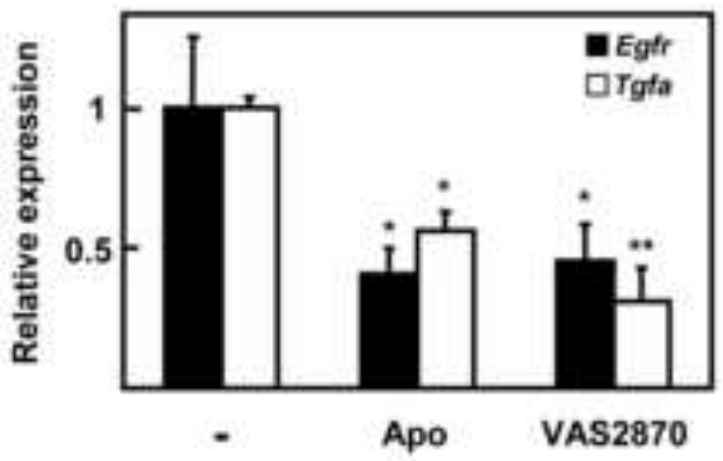

C

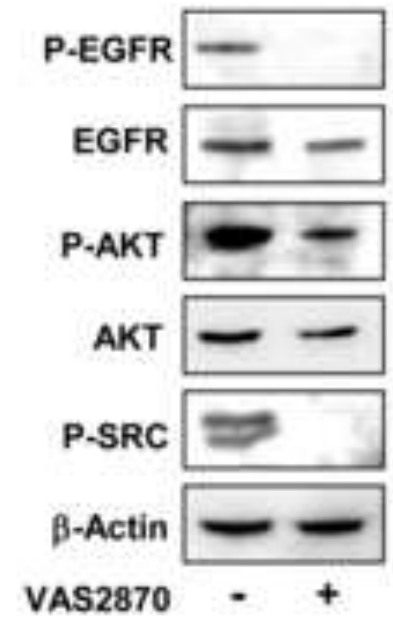

Figure 3 


\section{Figure 4}

Click here to download high resolution image

A

B
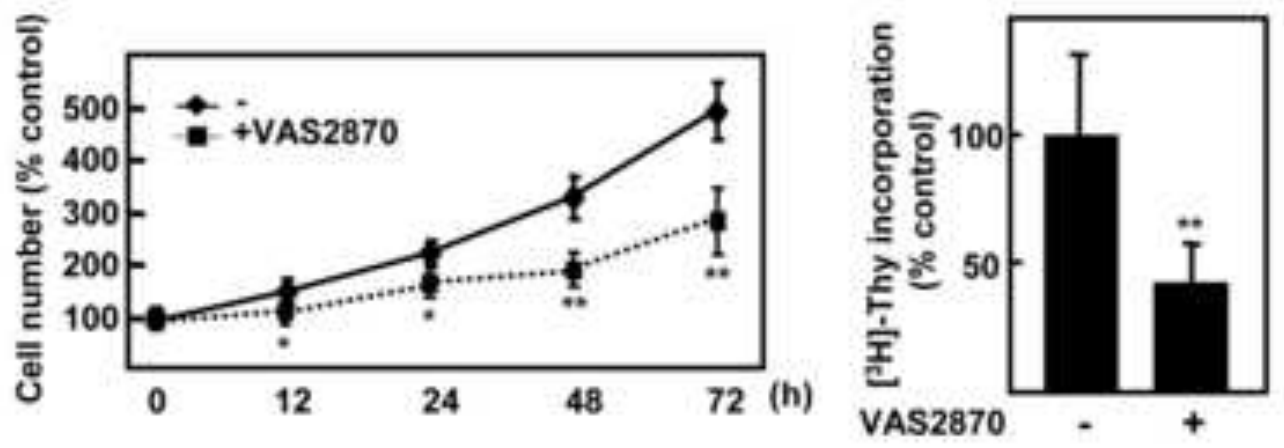

C
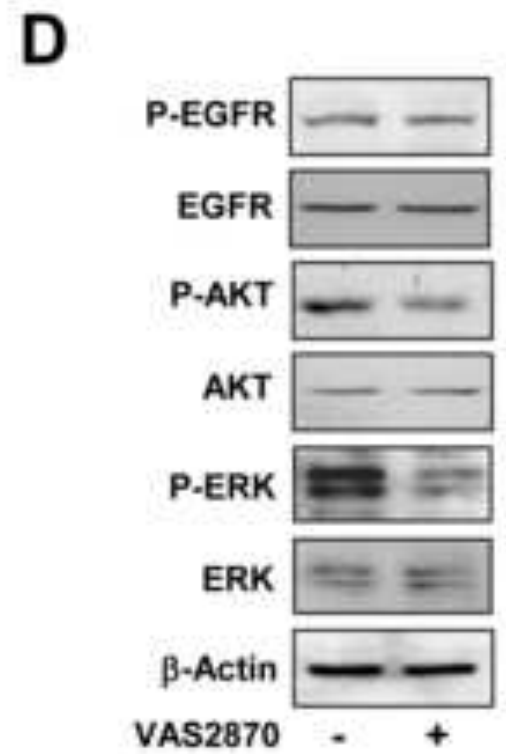

Figure 4 
A
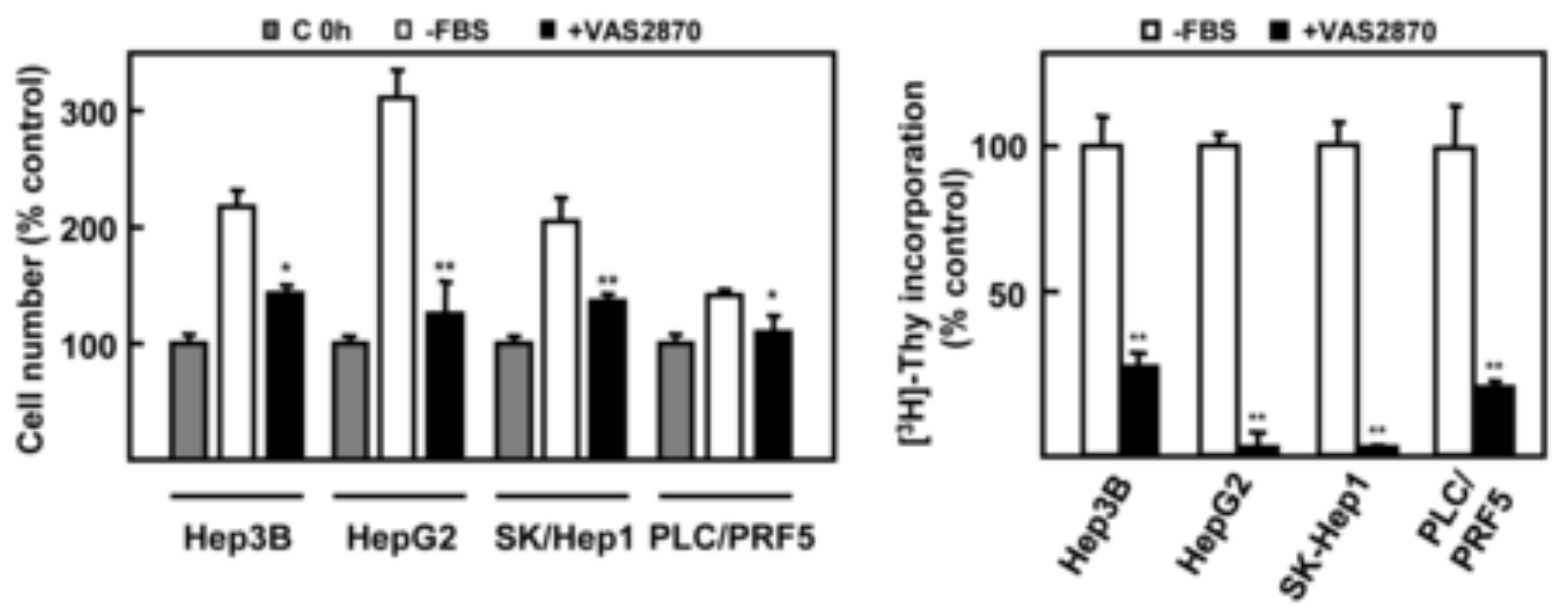

B
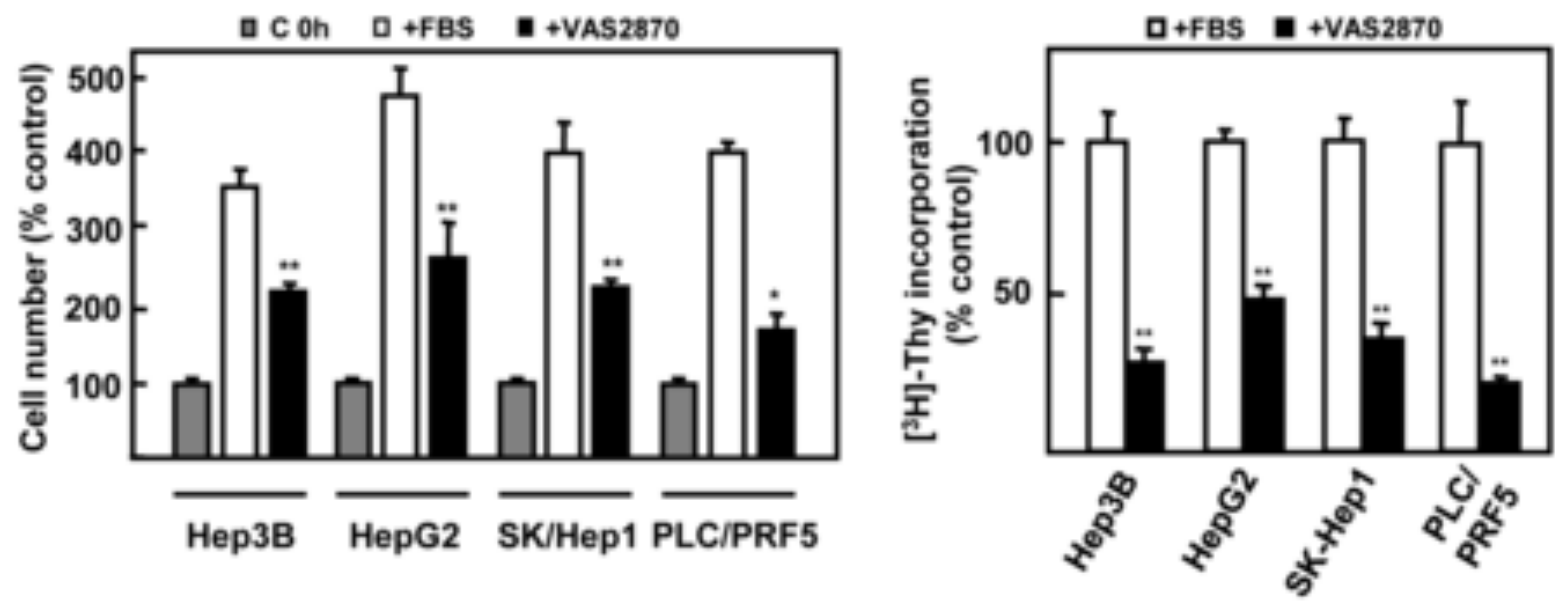

Figure 5 
A

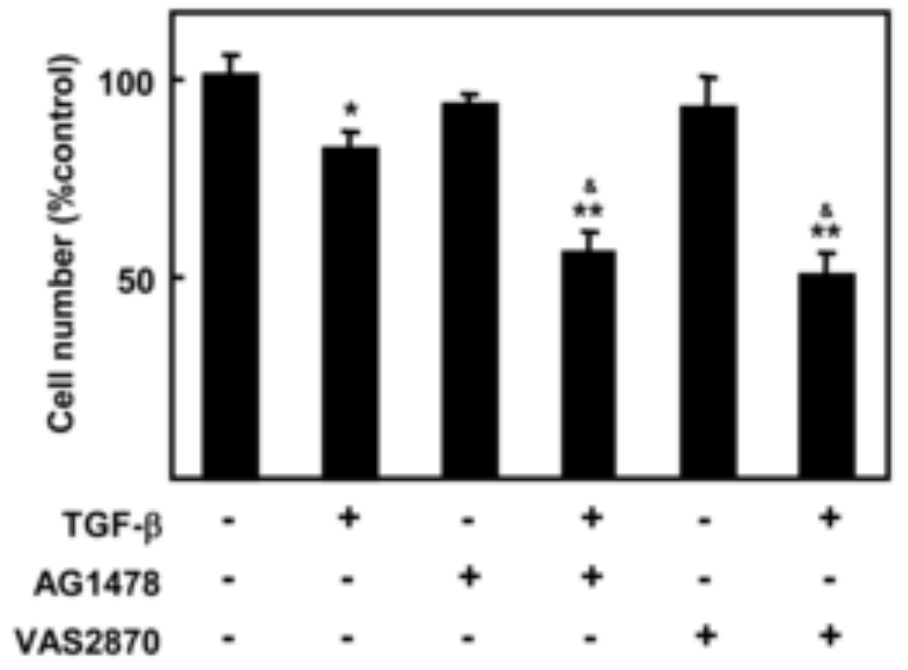

B

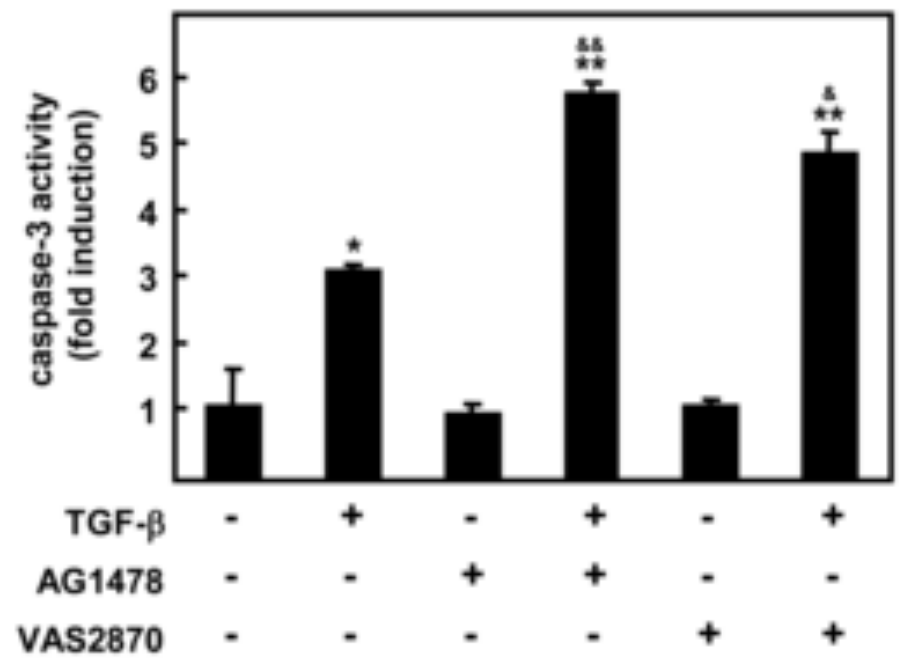

Figure 6 

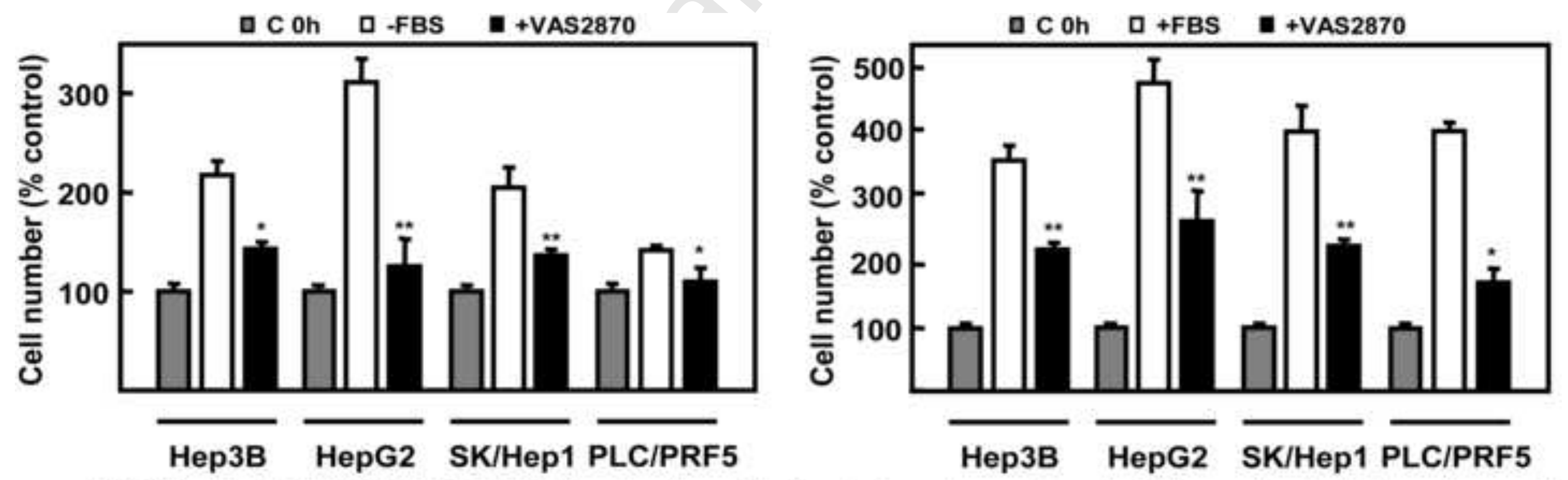

NADPH oxidase inhibitor VAS2870 effectively impairs cell growth both autocrine and serum-dependent of human hepatocellular carcinoma cells

Graphical abstract 